\title{
Effectiveness of Simulation-Based Cooperative Learning Method in Electrocardiography Education
}

\author{
Yasemin Uslu' ${ }^{1}$ (D) , Vildan Kocatepe ${ }^{1}$ (iD , Vesile Ünver ${ }^{1}$ iD , Ükke Karabacak ${ }^{1}$
}

${ }^{1}$ Acibadem Mehmet Ali Aydinlar University, Nursing Department, Istanbul, Turkey

Yasemin USLU, Dr. Öğr. Üyesi Vildan KOCATEPE, Dr. Öğr. Üyesi Vesile ÜNVER, Prof. Dr. Ükke KARABACAK, Prof. Dr.

Correspondence: Vesile Ünver Acibadem Mehmet Ali Aydinlar University, Nursing Department, Istanbul, Turkey Phone: 05379646859

E-mail: vunver1@gmail.com

Received

\section{ABSTRACT}

Objective: The study was conducted to evaluate the effectiveness of basic electrocardiography education designed in accordance with the simulation-based cooperative learning method.

Methods: This is a single group, quasi-experimental study. A two-day electrocardiography (ECG) education program was designed for the nursing internship (4th year) program $(n=125)$. Data were gathered with pre-posttest, Students' Satisfaction and Self-Confidence Scale, Simulation Design Scale and Educational Practices Questionnaire.

Results: The knowledge pretest score and the knowledge posttest score averages of the students were $40.36 \pm 20.24$ and $75.39 \pm 11.46$ respectively, with a significant difference $(p=.001 ; t=-14.78)$. The mean score for satisfaction with current learning was $4.77 \pm .42$ and the mean score for self-confidence was $4.51 \pm .54$. The mean total score for Simulation Design Scale was $4.44 \pm .67$ and the mean total score for Educational Practices Questionnaire was 4.66 \pm .56 .

Conclusion: After simulation-based cooperative learning method, knowledge and skills of the students improved also had high self-confidence and satisfaction with learning.

Keywords: Electrocardiography, simulation-based experience, cooperative learning, nursing education

\section{Simülasyona Dayalı İşbirlikçi Öğrenme Modeline Göre Tasarlanan Temel EKG Kursu'nun Etkinliği}

ÖZET

Amaç: Bu çalışma, Simülasyona Dayalı İşbirlikçi Öğrenme Modeli'ne göre tasarlanan Temel Elektrokardiyografi (EKG) Kursu'nun etkinliğini değerlendirmek amacıyla yapıımıştır.

Yöntem: Tek gruplu, yarı deneysel bir çalışmadır. Hemşirelik intörn öğrencilerine (4. sınıf) 2 günlük EKG eğitim programı tasarlandı ( $n=125$ ). Veriler ön-son test bilgi formu, Öğrencilerin Memnuniyet ve Öz-Güven Ölçeği, Simülasyon Tasarımı Ölçeği ve Eğitim Uygulamaları Anketi ile toplanmıştır.

Bulgular: Öğrencilerin kurs öncesi bilgi puan ortalamaları $40.36 \pm 20.24$, kurs sonrası puan ortalamaları $75.39 \pm 11.46$ olup istatistiksel olarak anlamlı bulundu $(\mathrm{p}=.001 ; \mathrm{t}=-14.78)$. Öğrenmede öğrenci memnuniyet puan ortalamaları $4.77 \pm .42$, özgüven puan ortalamaları ise $4.51 \pm .54$ 'dür. Simulasyon tasarımı toplam puan ortalamaları $4.44 \pm .67$, Eğitim Uygulamaları toplam puan ortalamaları $4.66 \pm .56$ 'dır.

Sonuç: Simülasyona Dayalı İşbirlikçi öğrenme modelinde kurs sonrası öğrencilerin bilgi ve beceri düzeylerini geliştirmiş ayrıca öğrenmede öğrenci memnuniyetleri ve özgüvenleri yükselmiştir.

Anahtar Kelimeler: Elektrokardiyografi, simülasyona dayalı öğrenme, işbirlikçi öğrenme, hemşirelik eğitimi 
ardiovascular diseases are the leading cause of death in Turkey and other countries; thus, treatment, care, and follow-up of patients with these conditions are important (1). Patients frequently arrive at emergency and intensive care units with cardiovascular diseases and receive critical care. In order for nurses to be able to maintain high-quality and effective care in these units, they are expected to be equipped with sufficient knowledge and skills about patients for whom they provide care $(2,3)$.

Emergency and intensive care nurses should be able to recognize sudden changes in patients earlier as well as implement appropriate interventions as quickly as possible. They should have adequate knowledge and skills to read monitors, perform ECG, interpret rhythms, and initiate interventions independently. As technology develops, it is also important that they use medical devices correctly (4).

Nurses having sufficient knowledge about the aforementioned skills; can carry out early and effective interventions, and save patients' lives. However, it has been reported in the literature that emergency and intensive care nurses do not have a sufficient level of knowledge about emergency ECG signs and interventions $(5,6)$. Several studies have shown that most nurses working in critical fields do not receive education about ECG, and that those that do receive education are not competent enough to evaluate ECG recordings and to design/start appropriate interventions (6). It is crucial to enhance nurses' knowledge so that they can offer more effective care and make fewer mistakes. It is recommended that nurses who actively perform and interpret ECG should be given experiential education about ECG at regular intervals (7-9). It has been noted in the literature that education based on a model and supported by different teaching methods like simulation helps nurses to improve their skills in recognizing the rhythms $(8,10)$.

Cooperative learning is one learning method in which students play active roles and work in groups of two or more to achieve the same goal $(11,12)$. It improves students' thinking and communication skills, encourages them to think critically, allows them to express their opinions throughout the learning process, and helps them to take responsibility for their learning. It creates an effective learning environment where students do not consider teachers as the only source of knowledge (12). Cooperative learning facilitates students' cooperation with each other in the learning process, and is thought to be achieved through simulation-based education when enhancing clinical skills in nursing.

Simulation is increasingly used in education, being rapidly integrated into curricula $(13,14)$. High-fidelity simulation is a simulation method that utilizes real mannequins, which are able to react to physiological results of diseases and injuries, treatments, and interventions (15). In simulation-based education, high-fidelity mannequins are most frequently used. In a systematic review of types of education using these mannequins, simulation-based education has been reported to be effective in recognizing changes in patients and in acquiring knowledge and skills (16).

This study was conducted to evaluate the effectiveness of basic ECG education designed in accordance with the simulation-based cooperative learning method.

\section{METHODS}

This single-group, quasi-experimental study with pre-and post-tests was performed with nursing internship (4th year) program at a university in Turkey. The study population comprised of final year nursing students at a nursing school in 2017 ( $n=125)$. Sixty-six students volunteered to participate in the study and took the Emergency Care and Intensive Care Nursing courses in Specific Fields. However, data from eleven students who did not take the pre and post-knowledge tests were not included in the analysis. Of all the participants, $18.1 \%(n=10)$ were male and $81.9 \%$ $(n=45)$ were female. All the students were informed about the study before taking basic ECG education.

Data Collection Tools: Data were gathered via pre and post-knowledge of ECG tests, Students' Satisfaction and Self-Confidence Scale (SCLS), Simulation Design Scale (SDS), and Educational Practices Questionnaire (EPQ). The pre- and post-tests were prepared by the researchers and were composed of ten questions measuring knowledge of ECG. One question of the test is presented in that SCLS, SDS, and EPQ are used to evaluate the effectiveness of simulation-based education $(17,18)$. They were developed by Jeffries in 2012, and their psychometric measurements were established by Franklin in $2014(18,19)$. Their validity and reliability for the Turkish population were tested by Unver et al. in 2017 (20).

Procedure: Within the framework of the Emergency Care and Intensive Care Nursing courses in Specific Fields, a two-day ECG education program was designed. It 
involved an eight-hour theoretical class and an eight-hour simulation class, which together lasted two days. On the first day, the students were offered theoretical knowledge through the conventional teaching method based on the goals of the education program, and they were provided with the content material. On the second day, the simulation was conducted in three steps.
First, the students applied skill training. Second, they were divided into groups and they interpreted ECGs in the cases given to them. Last, they took a knowledge quiz (Table 1). To evaluate the effectiveness of the education, the students were administered the pre-test involving questions about knowledge of ECG rhythms before the theoretical class, as well as the post-test involving the same questions after the simulation class.

\section{Table 1: Content of Education - Simulation Center}

\section{Step 1: I perform ECG correctly}

\section{Applied Skill Training}

The students monitored the mannequins, read and interpreted ECG values and placed ECG leads under the supervision of a trainer.
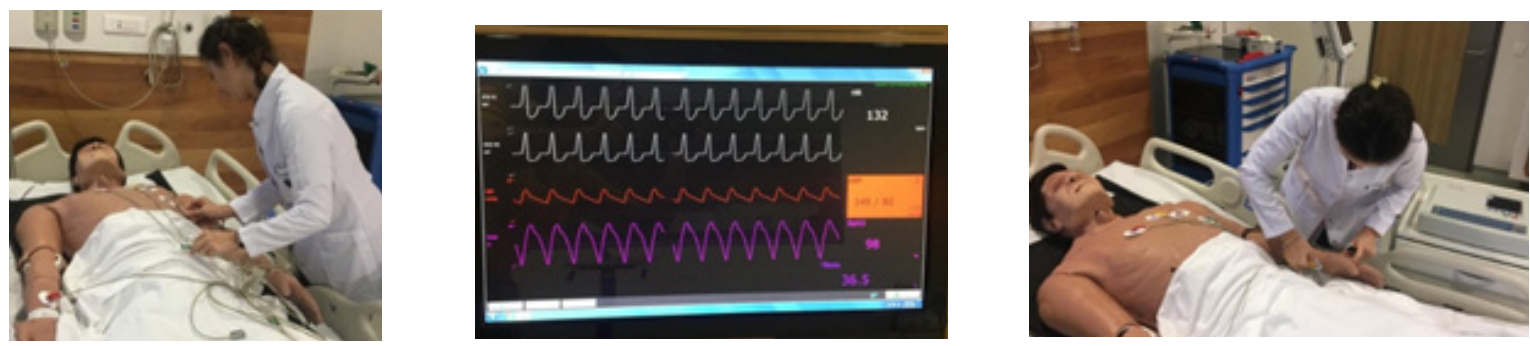

\section{Step 2: Workshop}

\section{Case Study}

The students were divided into seven groups, each having three students. Target nine ECG rhythms were printed out. Images of each rhythm were given to the students in order and the students were asked to record the information about the rhythms asked in the ECG interpretation form. They were encouraged to discuss their interpretations in their groups and they were given 10 minutes to interpret each rhythm.
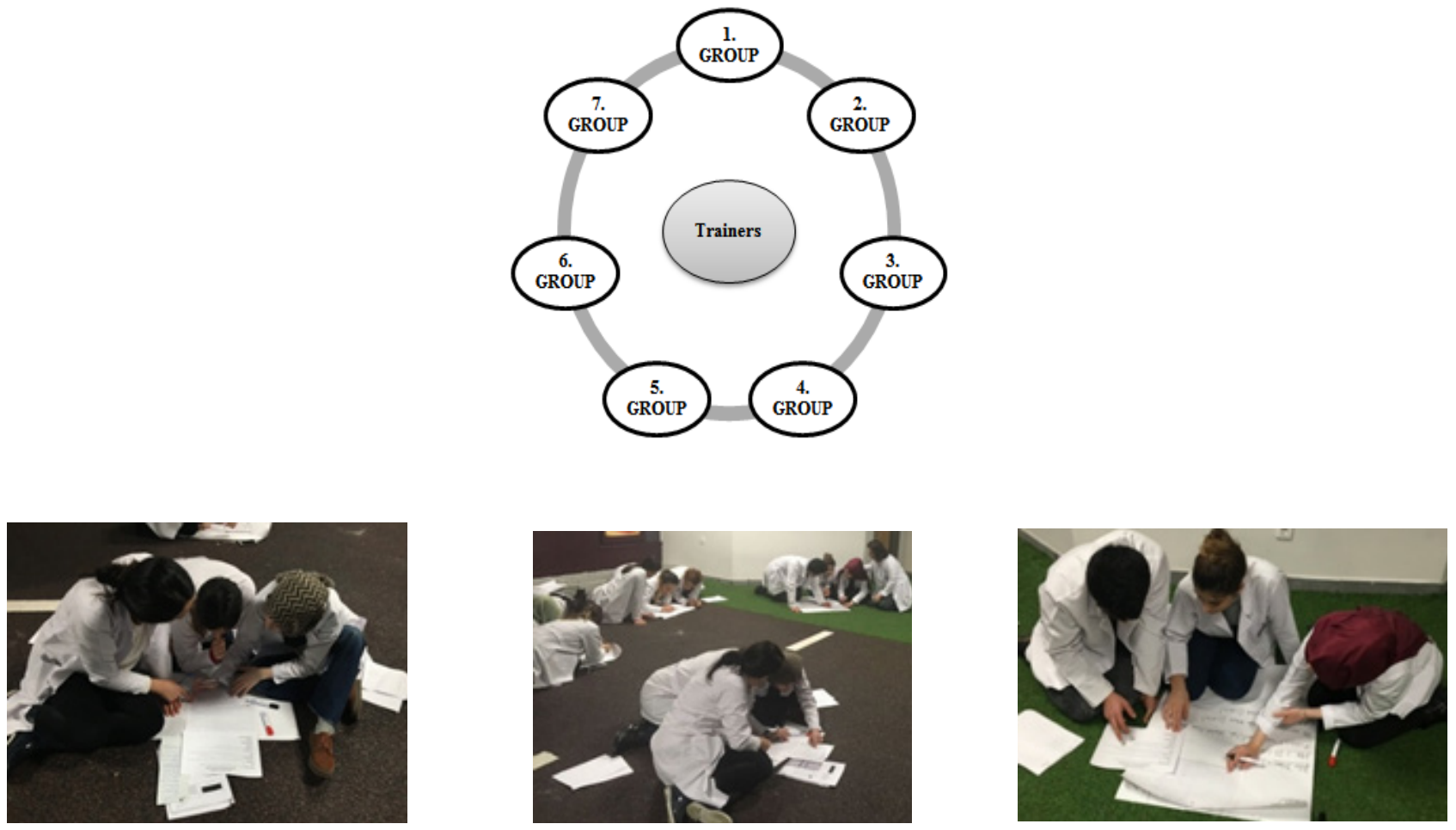

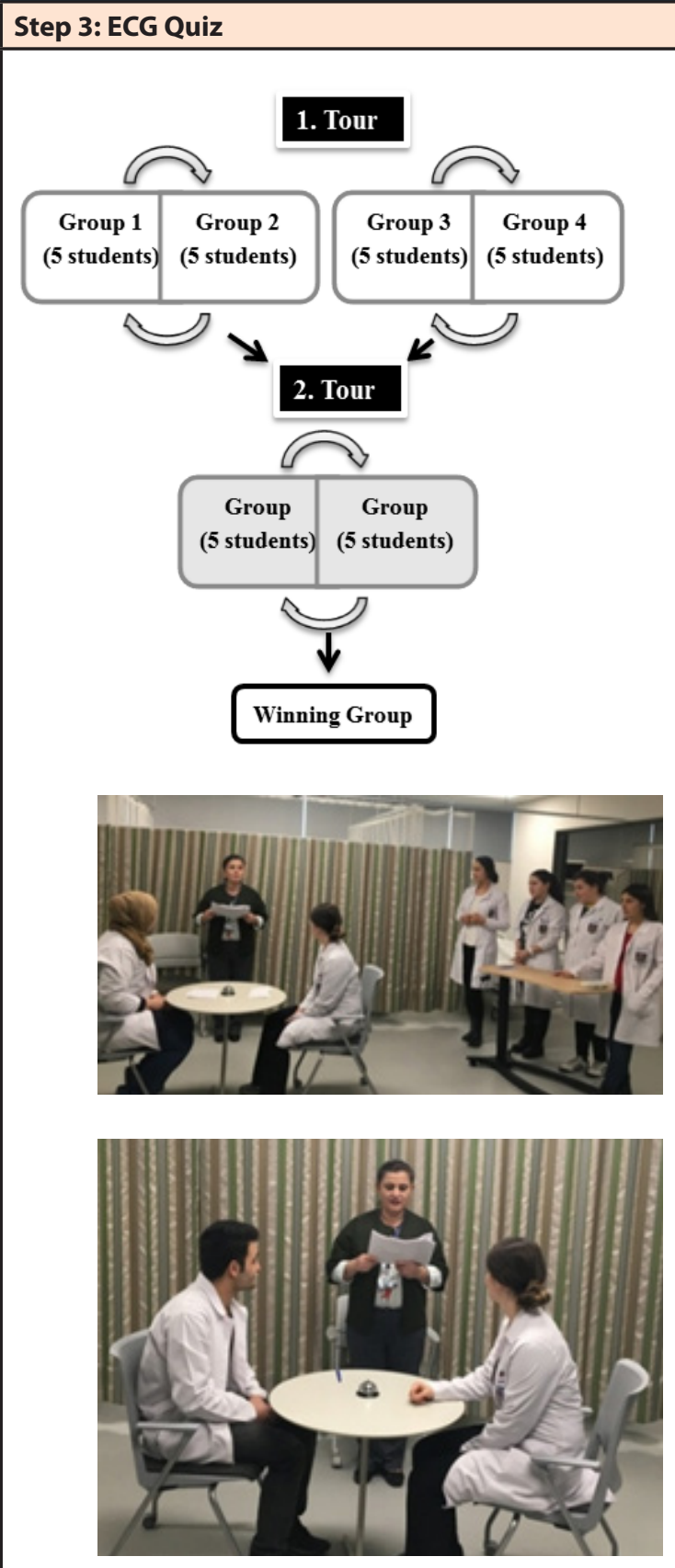

The students were randomly assigned into groups and each group included five students. In the first round, the groups were matched in pairs and they competed against each other. The winners got the right to join the quiz in the second round. The group winning the competition in the second round was rewarded.

\section{Rules of the Quiz:}

- The group members are seated and one member gets ready to ring the bell every time a question is asked.

- The member wanting to answer a question rings the bell and gives his/her answer.

- If he/she gives the correct answer, he/she gets points. After that, another member gets ready to answer the next question.

- If he/she gives a wrong answer, the rival team gets the right to answer the question. If a member of the rival group gives the correct answer, that groups gets points.

- If both groups give a wrong answer, they discuss the question. Whichever group rings the bell first gets the right to answer the question.

- In each round, the group providing the highest number of correct answers passes that round. If there is a draw, one more question is asked and the group answering that question first wins.

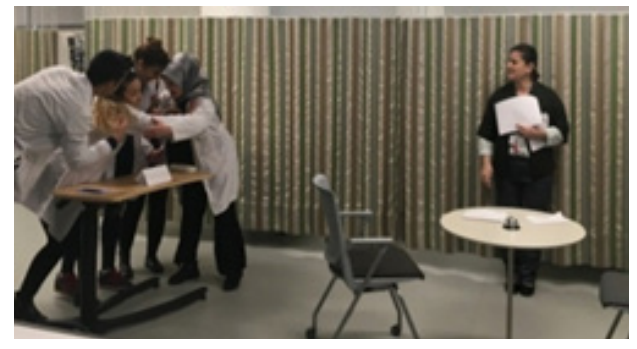




\section{Statistical Analysis}

Data were analyzed with the Statistical Package for Social Sciences (SPSS, Inc., Chicago, IL, USA) for Windows version 21.0. The normality of data was tested with the Kolmogorov-Smirnov test. The descriptive statistics; mean and standard deviation, minimum-maximum values, frequency, and percentage were used. The results obtained were compared by using Wilcoxon Signed-Ranks Test. A p-value of $<0.05$ was considered statistically significant.

\section{RESULTS}

The pre- and post-tests results, satisfaction with learning, self-confidence, simulation design, and educational practices were evaluated. Table 2 presents the mean scores for the pre- and post-tests. The mean pre-test knowledge score was $40.36 \pm 20.24$, and the mean post-test knowledge score was $75.39 \pm 11.46$; there was a significant difference $(p=.001, t=-14.78)$. Table 3 outlines the mean scores for satisfaction with learning and self-confidence, simulation design, and educational practices. The mean score for satisfaction with current learning was $4.77 \pm 42$, and the mean score for self-confidence was $4.51 \pm 54$. The mean score for simulation design was $4.44 \pm 67$, and the mean score for educational practices was $4.66 \pm 56$.

\section{Table 2. Pre- and Post-Tests Knowledge Scores ( $\mathrm{N}=55$ )}

\begin{tabular}{|l|c|c|c|}
\hline Score & Min-Max & $\overline{\mathrm{X}} \pm \mathrm{SD}$ & Statistical test* \\
\hline Pre-test & $0-75$ & $40.36 \pm 20.24$ & $\mathrm{t}=-14.78$ \\
\hline Post-test & $43-95$ & $75.39 \pm 11.46$ & $\mathrm{P}=0.01$ \\
\hline *Wilcoxon Signed Ranks Test \\
\hline
\end{tabular}

Table 3. Students' Satisfaction and Self-Confidence Scale, Simulation Design Scale and Educational Practices Scores $(\mathrm{N}=55)$

\begin{tabular}{|l|c|c|}
\hline & Min-Max & $\bar{X} \pm$ SD \\
\hline Satisfaction with Current Learning & $3-5$ & $4.77 \pm .42$ \\
\hline Self-confidence in Learning & $2.71-5$ & $4.51 \pm .54$ \\
\hline Simulation Design Scale & $3-5$ & $4.56 \pm .57$ \\
\hline Objectives and Information & $2-5$ & $4.32 \pm .82$ \\
\hline Support & $1.6-5$ & $4.39 \pm .81$ \\
\hline Problem-Solving & $1.25-5$ & $4.59 \pm .69$ \\
\hline Feedback/Guided reflection & $1-5$ & $4.33 \pm .95$ \\
\hline Fidelity(Realism) & $1.77-5$ & $4.44 \pm .67$ \\
\hline Total & & \\
\hline Educational Practices Questionnaire & $2.3-5$ & $4.54 \pm .59$ \\
\hline Active learning & $2.5-5$ & $4.69 \pm .57$ \\
\hline Collaboration & $1-5$ & $4.71 \pm .68$ \\
\hline Diverse Ways of Learning & $1.5-5$ & $4.7 \pm .61$ \\
\hline High Expectations & $1.83-5$ & $4.66 \pm .56$ \\
\hline Total & & \\
\hline
\end{tabular}

\section{DISCUSSION}

At present, cardiovascular diseases are the leading cause of death (21). Course content about the prevention and treatment of these diseases along with care for patients with these diseases were described in the National Nursing Core Curriculum in 2014 (22).

Many studies have shown that nurses do not have sufficient basic knowledge and skills of ECG. This evidence led nursing educators to utilize different models and methods to teach ECG $(2-4,23)$. Prior studies have used online web-based programs (e-learning) (24) algorithms (25), dance and movement (26), and the six-stage method (27) to help nurses recognize ECG rhythms and plan appropriate interventions. Unlike the reported studies, in the present study, the teaching method that was employed was designed in accordance with the simulation-based cooperative learning.

\section{Knowledge of ECG}

The students scored very high on the post-test. The mean test score increased from $40.36 \pm 20.24$ to $75.39 \pm 11.46$ (Table 2). It is known that cooperative learning, an active learning strategy, helps in acquiring desirable educational skills and attitudes like academic success, social skills, ability to express opinions, and critical thinking skills (12). Therefore, the learning outcomes of skill training in the cooperative learning method can be equal to and even better than those achieved through individual learning (28). It has also been reported that pedagogically-shared efforts in cooperative learning positively affect learning (29). In fact, student contributions to their peers' learning through the intragroup exchange of knowledge and discussions might have increased the post-test scores in the present study.

The simulation-based education utilized to teach ECG skills in the present study increases the fidelity of nursing education programs and is effective in improving critical thinking skills, ability to recognize changes in ECG monitors, and psychomotor skills in nursing students (16). The simulation-based method in nursing education-in which two-thirds of the curriculum involves practice-is important to improve psychomotor skills (30-32); furthermore, there is evidence that this method contributes to patient care. Performing practices in a high-fidelity environment provide students with an opportunity to enhance their decision-making and problem-solving skills and experience cases they may rarely encounter in their real life $(30,33)$. 
In the present study, thanks to the simulation-based method, the students had a chance to recognize basic ECG rhythms and in particular manage lethal arrhythmia. The literature reports that offering theoretical knowledge combined with using simulation to teach ECG increases nurses' success. It has been emphasized that both paperbased and electronically-monitored ECG rhythms should be utilized since their interpretations can be different (34). In the present study, the students worked in groups to analyze ECG cases. They experienced rhythm interpretation techniques by using electronically-recorded rhythms from the mannequins.

The students placed ECG leads on the mannequins and interpreted the rhythms they obtained, which strengthened their psychomotor skills (Table 3). It has been noted in the literature that offering theoretical knowledge along with using simulation for skill training increases students' success (35). In a study by Alinier et al. (2004), a significant increase was detected in psychomotor and cognitive skills following simulation-based education (36). In a systematic review, simulation-based education was recommended as preferable, since it enhances the psychomotor skills of nurses (31).

In the current study, the students were given various ECG cases to improve their critical thinking skills. The students worked in groups to analyze and discuss these cases. Many studies have shown that discussions in groups revolving around case analyses can ameliorate critical thinking skills $(37,38)$. Consistent with the literature, in the present study, knowledge quizzes conducted for a general revision of what was learned showed an improvement in the students' ability to make quick decisions about ECG.

\section{Students' Satisfaction and Self-Confidence}

As a result of the simulation-based education, the mean scores for current student satisfaction with learning

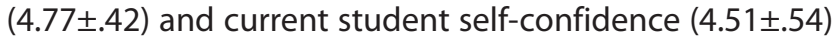
increased (Table 3). The students noted that the teaching methods used in education were effective, motivating, and helpful for learning. In a study of the effects of simulation-based ECG education on critical thinking and selfconfidence, the students in the simulation group had higher self-confidence (42). Comparable with the literature $(37,39,40)$, the students in the present study were found to be satisfied with the simulation-based education and were self-confident in terms of their skills.

\section{Educational Practices}

The mean total score for educational practices was $4.66 \pm .56$, which was very high. Sumner et al. found that simulation in which nurses actively participated was effective in learning ECG (8). In a study by Brannan et al., the effectiveness of a classroom lecture was compared to the use of simulation in terms of knowledge gain. They showed that education given through simulation-based learning about patients with acute myocardial infarction led to a significant increase in the post-test scores of the students, compared to the education given through the conventional method (41). The results of the present study also suggest that the active learning underlying simulation-based education has positive effects on students.

\section{Simulation Design}

The mean total score for simulation design was 4.44 \pm .67 , which indicated that the simulation-based ECG education was very effective (Table 3). National Council of State Boards of Nursing reported that it is difficult to create evidence-based practices due to lack of standardization, although it supports using simulation in education. Therefore, it is recommended that educational content should be created using the best-practice standards provided by the International Nursing Association for Clinical Simulation and Learning, and that the education should be evaluated with valid and reliable tools (42). The mean high score for simulation design in the present study can be attributed to the simulation education planned in accordance with the best-practice standards.

\section{CONCLUSION}

Basic ECG education that is developed in accordance with the simulation-based cooperative learning model created positive learning outcomes. The use of different teaching techniques and the active involvement of the students were found to positively influence learning. It was also observed that the students contributed to their peers' learning. In addition, the students' self-confidence and satisfaction with learning increased. However, further studies are needed to evaluate the effectiveness of the model in terms of learning outcomes, satisfaction, and self-confidence in different subjects.

\section{Limitations}

The fact that this study was performed in only one nursing school restricts the generalizability of its results. 


\section{Compliance of Ethical Statement}

Ethical approval was obtained before starting the study from the ethical committee of the university where the study was conducted (approval number: 2017-13/7). We are allowed to use pictures of the students.

\section{Conflict of Interest}

All authors declare no conflict of interest.

\section{Acknowledgments}

None declared.

\section{Financial Disclosure/Statement \\ None declared.}

\section{Author Contribution}

All authors contributed equally to the preparation of this article.

\section{REFERENCES}

1. Pagidipati NJ, Gaziano TA. Estimating Deaths from Cardiovascular Disease: A Review of Global Methodologies of Mortality Measurement. Circulation. 2013;127(6):749-56.

2. ÇelikY, Karadaş C, Akdağ C, Özkeçeci G. Evaluation of ECG Knowledge of the Employees in the Emergency and Intensive Care Nurses. Turkish Journal of Cardiovascular Nursing. 2015;6(9):75-85.

3. Doğu Ö, Gündüz H, Dede E. An Evaluation of the State of Cardiology, Intensive Care and Emergency Nurses' Recognizing the Findings of ECG and Their Initiatives of Appropriate Nursing. Sakarya Medical Journal. 2014:4(4):178-81.

4. Göz F, Baran G. Determining of the Nurses Assessments about ECG and Need of Education. Journal of Cumhuriyet University School of Nursing. 2000;4(2):33-9.

5. Keller K, Raines D. Arrhythmia Knowledge: A Qualitative Study. Heart \& Lung: The Journal of Acute and Critical Care. 2005;34(5):309-16.

6. Nickasch B, Marnocha S, Grebe L, Scheelk H, Kuehl C. 'What Do I Do next?'Nurses' Confusion and Uncertainty with ECG Monitoring. MedSurg Nursing. 2016;25(6):418-23.

7. Özoğul A, Yolaçan A, Erkuş B. Evaluating the Education Results of the Nurses Who Had Basic Electrocardiography Education in Acıbadem Health Group: Recognizing Deadly Rythms. Turkish Journal of Cardiovascular Nursing. 2015;6(10):112-20.

8. Sumner L, Burke $S$, Chang L, McAdams M, Jones D. Evaluation of Basic Arrhythmia Knowledge Retention and Clinical Application by Registered Nurses. Journal for Nurses in Professional Development. 2012;28(2):E5-E9.

9. Üzel G, Ulupınar S. Knowledge and Opinions of Nurses about Electrocardiography. Journal of the Turkish Society of Critical Care Nurse 2011;15(1):1-8.

10. Granero-Molina J, Fernández-Sola C, López-Domene E, HernándezPadilla J, Preto L, Castro-Sánchez A. Effects of Web-Based Electrocardiography Simulation on Strategies and Learning styles. Revista da Escola de Enfermagem da USP. 2015;49(4):0650-6.

11. Dillenbourg P. What Do You Mean by Collaborative Learning? P. Dillenbourg ed: Oxford: Elsevier; 1999. p. 1-19.
12. Şimşek U, Şimşek Ü, Doymuş K. A Review on Cooperative Learning Method III: the Useful in Education Environment of Cooperative Learning Method Atatürk University Kazım Karabekir Education Faculty Journal 2006(13):415-28.

13. Solnick A, Weiss S. High fidelity Simulation in Nursing Education: a Review of the Literature. Clinical Simulation in Nursing. 2007;3(1):41-5.

14. Aebersold M, Tschannen D. Simulation in Nursing Practice: the Impact on Patient Care. Online Journal of Issues in Nursing. 2012;18(2):6-.

15. Decker S, Sportsman S, Puetz L, Billings L. The Evolution of Simulation and Its Contribution to Competency. The Journal of Continuing Education in Nursing. 2008;39(2):74-80.

16. Lapkin S, Levett-Jones T, Bellchambers $\mathrm{H}$, Fernandez R. Effectiveness of Patient Simulation Manikins in Tteaching Clinical Rreasoning Skills to Undergraduate Nursing Students: A Systematic Review. Clinical Simulation in Nursing. 2010;6(6):e207-e22.

17. Basak T, Unver V, Moss J, Watts P, Gaioso V. Beginning and Advanced Students' Perceptions of the Use of Low-and Highfidelity Mannequins in Nursing Simulation. Nurse Education Today. 2016:36:37-43.

18. Jeffries P. Simulation in Nursing Education: from Conceptualization to Evaluation. 2nd ed. ed. National League for Nursing, New York 2012.

19. Franklin A, Burns P, Lee C. Psychometric Testing on the NLN Student Satisfaction and Self-Confidence in Learning, Simulation Design Scale, and Educational Practices Questionnaire Using a Sample of Pre-Licensure Novice Nurses. Nurse Education Today. 2014;34(10):1298-304.

20. Unver V, BasakT, Watts P, Gaioso V, Moss J, Tastan S, et al. The Reliability and Validity of Three Questionnaires: The Student Satisfaction and Self-Confidence in Learning Scale, Simulation Design Scale, and Educational Practices Questionnaire. Contemporary Nurse. 2017:53(1):60-74.

21. The Top 10 Causes of Death http://www.who.int/mediacentre/ factsheets/fs310/en/: World Health Organization; [Access Date 30.01.2018 ]

22. Kaya H. National Core Training Program for Nursing http://www. hemed.org.tr/images/stories/hucep-2014-pdf.pdf. 2016 [

23. Rajakumari G, Kumar S, Soli T. Effectiveness of Structured Education on Electrocardiograph Findings Among Nursing Students. Journal of Science. 2015;5(9):787-90.

24. Kim Y. Effects of a Web-Based Teaching Method on Undergraduate Nursing Students' Learning of Electrocardiography. Journal of Nursing Education. 2005;44(1):35.

25. Atwood D. Using an Algorithm to Easily Interpret Basic Cardiac Rhythms. AORN journal. 2005;82(5):757-66.

26. Schultz K, Brackbill M. Teaching Electrocardiogram Basics Using Dance and Movement. American Journal of Pharmaceutical Education. 2009;73(4):70.

27. Varvaroussis $D$, Kalafati $M$, Pliatsika $P$, Castrén $M$, Lott $C$, Xanthos T. Comparison of Two Teaching Methods for Cardiac Arrhythmia Interpretation among Nursing Students. Resuscitation. 2014;85(2):260-5.

28. Tolsgaard M, Kulasegaram K, Ringsted C. Collaborative Learning of Clinical skills in Health Professions Education: The Why, How, When and for Whom. Medical Education. 2016;50(1):69-78.

29. Wulf G, Shea C, Lewthwaite R. Motor Skill Learning and Performance: a Review of Influential Factors. Medical Education. 2010;44(1):75-84.

30. Durmaz Edeer A, Sarıkaya A. The Use of Simulation in Nursing Education and Simulation Types. Journal of Education and Research in Nursing. 2015;12(2):121-5. 
31. Kim J, Park J, Shin S. Effectiveness of Simulation-Based Nursing Education Depending on Fidelity: a Meta-Analysis. BMC Medical Education. 2016;16(1):152.

32. Eyikara E, Baykara Z. The Importance of Simulation in Nursing Education. World Journal on Educational Technology: Current Issues. 2017;9(1):2-7.

33. Kunst $E$, Mitchell $M$, Johnston A. Using Simulation to Improve the Capability of Undergraduate Nursing Students in Mental Health Care. Nurse Education Today. 2017;50:29-35.

34. Smith N, Prybylo S, Conner-Kerr T. Using Simulation and Patient Role Play to Teach Electrocardiographic Rhythms to Physical Therapy Students. Cardiopulmonary Physical Therapy Journal. 2012;23(1):36.

35. Kardong-Edgren S, Anderson M, Michaels J. Does Simulation Fidelity Improve Student Test Scores? Clinical Simulation in Nursing. 2007;3(1):e21-e4.

36. Alinier G, Hunt W, Gordon R. Focus: Determining the Value of Simulation in Nurse Education: Study Design and Initial Results. Nurse Education in Practice. 2004;4:200-7.

37. Howard V. A comparison of Educational Strategies for the Acquisition of Medical-Surgical Nursing Knowledge and Critical Thinking Skills: Human Patient Simulator vs. the Interactive Case Study Approach. PA: University of Pittsburgh: University of Pittsburgh; 2007.

38. Ravert P. Patient Simulator Sessions and Critical Thinking. Journal of Nursing Education. 2008;47(12):557-62.

39. Smith S, Roehrs C. High-Fidelity Simulation: Factors Correlated with Nursing Student Satisfaction and Self-Confidence. Nursing Education Perspectives. 2009;30(2):74-8.

40. Jeffries $P$, Rizzolo M. Designing and Implementing Modelsfor the Innovative Use of Simulationto Teach Nursing Care of III Adults and Children: A National, Multi-Site, Multi-Method Study National League for Nursing. 2006.

41. Brannan J, White A, Bezanson J. Simulator Effects on Cognitive Skills and Confidence Levels. Journal of Nursing Education. 2008;47(11):495-500.

42. Doolen J, Mariani B, Atz T, Horsley T, O'Rourke J, McAfee K, et al. High-fidelity Simulation in Undergraduate Nursing Education: A Review of Simulation Reviews. Clinical Simulation in Nursing. 2016;12(7):290-302. 